\section{УДК 659.441}

JEL M11, O22, L14

DOI 10.31375/2226-1915-2021-1-76-86

\section{УПРАВЛІННЯ ПРОСКТАМИ} ЗГІДНО 3 ТРЕНДАМИ ЕVЕNТ-ГАЛУЗІ

К.Л. Семенчук

к.т.н., доцент, доцент кафедри

управління логістичними системами і проєктами

Orcid ID 0000-0002-1808-448X mailto:katarix@ukr.net Д.Д. Нечит

магістр спеціальності 073 «Менеджмент», освітньо-професійна програма

«Управління проєктами» nechit99@gmail.com

Одеський начіональний морський університет, Одеса, Украӥна

Анотація. У роботі розглядається один iз перспективних напрямів сучасності - івентзаходи. Період пандемії короновіруса в 2020 рочі надав значний вплив на всі сфери економічноі діяльності країн світу, при иьому однією з особливо постраждалих галузей стала івент-індустрія. Відмова усіх офлайн заходів, введення протиепідемічних обмежень призвели до необхідності докорінної перебудови діяльності як в івент-галузі, так і освітній діяльності, що характеризує перехід до дистаційного навчання. В умовах сьогодення необхідно враховувати перспективи розвитку івент-галузі та виявити проблемні аспекти таких заходів в онлайн форматі, в тому числі для надання освітніх послуг. До тенденцій розвитку івентів на майбутне відносимо:

1. Мікро-взаємодію та персоналізацію. пандемії.

2. Безпечність івент-заходів в умовах онлайн.

3. Окупність подій при проведенні їх

4. Гібридні івенти - че майбутне івентіндустрії. Ймовірно, що учасники, які входять до «групи ризику», віддадуть перевагу підключитися до заходу онлайн.

5. Нові пріоритети в проведені івентзаходів. Віртуальні події вимагають інновацій, творчості та відмову від старих підходів.

6. Аудіо-формат - як альтернатива платформи ZООМ. Це нова можливість придбання квитків для платних віртуальних подій.

7. Переосмислення емоційної залученості відвідувачів. Віртуальні подіі - на відміну від класичних - не можуть задіяти всі почуття ayduторіï.

Також відокремлені переваги для основних учасників (організатора та доповідача) науково-практичної конференції.

Ключові слова: івент-технології, управління івент-проєктом, проєктний менеджмент, проєкт, розвиток, перспективи.

() Семенчук К.Л., Нечит Д.Д., 2021
УДК 659.441

JEL M11, O22, L14

DOI 10.31375/2226-1915-2021-1-76-86

\section{УПРАВЛЕНИЕ ПРОЕКТАМИ СОГЛАСНО С ТРЕНДАМИ ЕVЕNT-OTРАСЛИ}

\section{Е.Л. Семенчук}

к.т.н., доцент, доцент кафедры «Управление логистическими системами и проектами»

Orcid ID 0000-0002-1808-448X

katarix@ukr.net Д.Д. Нечит

магистр специальности 073 «Менеджмент» образовательно-профессиональная программа «Управление проектами» nechit99@gmail.com

Одесский начиональный морской университет, Одесса, Украина

Аннотация. В работе рассматривается одно из перспективных направлений современности - ивент-мероприятия. Период пандемии короновируса в 2020 году оказал значительное влияние на все сферы экономической деятельности стран мира, при этом одной из особенно пострадавших отраслей стала ивент-индустрия. Отказ всех офрлайн мероприятий, введение протиивоэпидемических ограничений привели к необходимости коренной перестройки деятельности как в ивент-отрасли, так и в образовательной деятельности, что характеризует переход к дистанционному обучению. В современных условиях необходимо учитывать перспективы развития ивент-отрасли и выявить проблемные аспекты таких мероприятий в онлайн формате, в том числе для образовательных услуг. К тенденциям развития ивентов в будущем относим:

1. Микро-взаимодействие и персонализачию.

2. Безопасность ивент-мероприятий в условиях пандемии.

3. Окупаемость событий при проведении их онлайн.

4. Гибридные ивенты - это будущее ивентиндустрии. Вероятно, что участники, входящие в «группу риска», предпочтут подключиться к мероприятию онлайн.

5. Новые приоритеты в проведении ивентмероприятий. Виртуальные события требуют инновачий, творчества и отказ от старых подходов.

6. Аудио-формат - как альтернатива платформы ZOOM.

7. Переосмысление эмоционального привлечения посетителей. Виртуальные события, в отличие от классических, не могут задействовать все чувства аудитории.

Также выделены преимущества для основных участников (организатора и докладчиков) научно-практической конференции.

Ключевые слова: ивент-технологии, уnравление ивент-проектом, проектный менеджмент, проект, развитие, перспективы. 


\author{
UDC 659.441 \\ JEL M11, O22, L14 \\ DOI 10.31375/2226-1915-2021-1-76-86
}

\title{
PROJECT MANAGEMENT ACCORDING TO EVENT INDUSTRY TRENDS
}

\author{
Kateryna Semenchuk \\ $\mathrm{PhD}$, docent, docent Department of Logistics System and Project Management \\ katarix@ukr.net \\ Daria Nechyt \\ Master in the specialty 073 «Management» \\ educational qualification program «Project Management» \\ nechit99@gmail.com

\section{Odessa National Maritime University, Odessa, Ukraine}

\begin{abstract}
The paper describes one of the most trends of our time-events. During the coronary virus pandemic in 2020 had a significant impact on all trends of economic activity in the world. One of the most affected industries was the event industry, namely the rejection of all offline measures, the introduction of anti-epidemic restrictions led to the need for radical restructuring of activities in both the event industry and educational activities, which is characterized by the transition to distance learning. In today's conditions, it is necessary to take into account the prospects for the development of the event industry in the period of COVID-19 and identify problematic aspects of such activities online, including the provision of educational services. The trends of future
\end{abstract} events:

1. Micro-experience and personalization. The concept of planning large events in exotic location will change dramatically in the scale of how these experiences will be planned.

2. Safety first. Representatives of the event industry are increasingly declaring the need for safety during events.

3. Making money with virtual. If the event organizers want to host a secure version of their event without having to consider social distancing, testing, tracing, sanitizing, travelling, and the possibility of being sued, virtual events are the only option.

4. Hybrid events are the future of the event industry. Offline events will not be able to gather all interested visitors. It is likely that participants in the "risk group» will prefer to join the event online.

5. New priorities in the events. Organizers need to set high objectives so that their virtual events arouse lively interest and a desire to pay for a ticket. Virtual events require innovation, creativity and the destruction of old approaches.

6. Audio format - as an alternative to the ZOOM platform. Offering audio attendance could help create new ticket opportunities to paid for virtual events as well as gi-ving more relaxed attendance options to those who feel overwhelmed by ZOOM meetings and virtual events invites.

7. Rethinking the emotional involvement of visitors. It should be considered online as a separate format that has nothing to do with traditional event. Virtual events cannot involve all the feelings of the audience - unlike the classic ones.

The advantages for the main participants (organizer and speaker) of the scientificpractical conference are also highlighted.

Keywords: event-technologies, event project management, project management, project, development, prospects 
Постановка проблеми. Управління проєктом івент-заходами охоплює методи та інструменти управління унікальними подіями, які розглядаються як окремі проєкти, що мають початок і закінчення, мету, завдання та обмежені ресурси на реалізацію. Згідно з класифікацією [1; 2], конференції, семінари, тренінги, круглі столи тощо відносять до ділових івентів.

Наукова конференція - це форма організації науково-практичної діяльності, учасники якої представляють і обговорюють свої наукові досягнення та здобутки.

Слід зазначити, що пандемія короновіруса значно вплинула на всі сфери економічної діяльності країн світу. Однією 3 особливо постраждалих галузей стала івент-індустрія, а саме - відмова усіх офлайн заходів, введення протиепідемічних обмежень призвели до необхідності докорінної перебудови діяльності як в івентгалузі, так і в освітній діяльності, що характеризує перехід до дистанційного навчання. В умовах сьогодення необхідно враховувати перспективи розвитку івент-галузі в період COVID-19 та виявити проблемні аспекти таких заходів в онлайн форматі, в тому числі при проведенні ділових та освітніх заходів.

Огляд останніх досліджень та публікацій. Дослідження питань івент-заходів, пов'язаних з розвитком цього напрямку та їх реалізацією займалися зарубіжні та українські науковці, такі як У. Хальбаур, А. Шон, Б. Перрі, Дж. Там, П. Нортон, Дж. Нева, О. Шумович, Н.М. Пономарьова, Г.В. Тульчинський та інші [25]. Однак, зміна зовнішнього та внутрішнього середовища в ділових заходах потребує додаткового дослідження, оскільки карантин та перехід до дистанційного навчання шляхом використання програмних продуктів, таких як Zoom, Microsoft Team тощо, a також орієнтація на студентськеорієнтоване навчання потребує но- вого підходу до проведення ділових заходів, зокрема в ВНЗ України. У [69] були визначені основні напрямки розвитку івент-заходів у поточному році, але не адаптовані до реалій проведення подібних подій в Україні.

Метою дослідження $\epsilon$ підвищення ефективності проєктів при плануванні та організації івент-заходів згідно з трендами галузі при реалізації ділових заходів, зокрема при проведенні науково-практичних конференцій в Одеському національному морському університеті.

Основний матеріал дослідження. В Україні event-ринок почав розвиватися 16 років тому, з 2005 року [2]. Експерти ринку сфери організації заходів в Україні називають його надзвичайно перспективним, але існують наступні проблеми [6]:

- відсутність на ринку майданчиків для комунікації агентств (асоціацій, галузевого співтовариства тощо);

- неготовність українських клієнтів до креативних рішень;

- дефіцит кваліфікованих кадрів на ринку.

Значним плюсом для eventіндустрії України стало проведення Євробачення-2017, що привернуло багато уваги зарубіжних інвесторів. Основні тенденції позитивного розвитку івент-ринку в Україні, які вже активно використовуються, наступні: збільшення кількості інтернет-ресурсів, друкованих видань, інформації в 3MI про event-індустрію; поява безлічі нових незалежних event-агентств; розширення спектру i поліпшення якості послуг, що надаються; прагнення до формування стандартів якості послуг event-індустрії; орієнтування на тренди: використання віртуальної реальності (VR - англ. «Virtual reality»), штучного інтелекту, змішання офлайну i онлайну тощо. Усі ці тенденції варто враховувати до бізнес-заходів. У 2016 році обсяг доходу від організації бізнес-заходів оцінили в 752 млрд. дол. А в 2023 
році очікується зростання аж до 1,2 трл. дол. [5]. Якщо говорити про Україну, то кількість аналогічних заходів зростає швидко. Починаючи від нарад, тренінгів, круглих столів, невеликих зустрічей всередині компаній, закінчуючи конференціями на кілька тисяч осіб.

Розглянемо основні тренди розвитку в івент-ідустрії, які слід враховувати при проведенні ділових заходів.

1. Мікро-взаємодія та персоналізація. Оскільки галузь івентменеджменту переосмислена в 2021 році, планування масштабних подій матиме масу ускладнень. Вони потребують перепланування. Тому виник новий вид напрямку, що допомагає організаторам подій використовувати більш персоналізований підхід та відповідний досвід. Це забезпечить івент-менеджерів можливостями для створення дивовижних та привабливих вражень, які задовольняють меншу кількість людей. Незважаючи на те, що ці івенти будуть малочисельні, вони $є$ більш приємними та менш ризикованими, ніж масштабні заходи у великих містах та на великих майданчиках. Принцип роботи цих напрямків для створення такого досвіду остаточно визначиться у 2021 році [9].

Менші за розмірами івенти матимуть безпрецедентну можливість пропонувати більш ексклюзивні події, які $є$ більш камерними, з обмеженими групами, які можуть розвивати більш значущі зв'язки між учасниками подіï. Великі заходи традиційно страждали від відсутності персоналізації. Здається, у галузі є потужна можливість переосмислити особисті зв'язки.

Галузеві експерти передбачають, що гібридні івенти матимуть менший відсоток відвідувачів «наживо» порівняно $з$ онлайном. Очевидно, що офлайн івенти повинні мати щось унікальне, щоб відвідувачі вирішили прийти «наживо». Експерти також вважають дуже цікавим дослідити, як івент-менеджери будуть узгоджувати свої дії з іншими колегами в умовах онлайну. Це назавжди змінить методи та інструменти івент-планування.

\section{2. Безпечність івент-заходів в} умовах пандемії. Представники івент-індустрії все голосніше заявляють про необхідність повернутися до проведення заходів. Перед багатьма компаніями постає питання про майбутнє їхнього бізнесу. Принаймні, організатори подій мають розуміти правила, за якими можна буде працювати найближчим часом. Однак, замість чітких інструкцій влада більшості країн світу реагує слабо, нервово і незрозуміло.

Немає сумнівів у тому, що в 2021 році те, як відвідувачі будуть оцінювати участь у заході, продиктоване, в першу чергу, безпекою. Звісно, багато 3 цих побоювань будуть врівноважені тим, коли і в якій мірі стануть доступними ефективні вакцини до широкого кола людства, але до того часу спеціалістам, які проводять заходи, потрібно буде суттєво розглянути заходи безпеки, що застосовуються для онлайн подій. Галузь івент-менеджменту влітку 2020 року стала свідком наслідків спалаху вірусу у багатьох країнах. У той час події почали повертатися, але безпека була першорядною 3 точки зору того, як учасники оцінювали, брати участь у заходах, чи ні. Далі перераховані пункти, які потрібно враховувати при проведені офлайн івент-заходів в умовах пандемії.

1. Не існує поняття ідеальної кількості учасників безпечного івенту. Але 50 чоловік на локації розумна межа.

2. Локальні івенти безпечніші. Присутність тільки місцевих учасників значно знижує ризик зараження: особливо якщо в місті або регіоні епідеміологічна ситуація контрольована.

3. Максимальна тривалість сесії - 30 хвилин. Це дозволить уникнути масового зараження учас- 
ників протягом довгого перебування в приміщенні.

4. Експрес-тестування на вході непрактично. Це створить черги, i учасники ризикують заразитися, стоячи в них.

5. Масковий режим в приміщенні - обов'язковий. Можливо, організаторам варто роздавати маски при вході.

6. Від багатоденних івентів краще відмовитися. Тривалі заходи значно підвищують ризик зараження учасників і обслуговуючого персоналу, з яким вони будуть контактувати.

Події, які будуть дотримуватись усіх цих пунктів, матимуть перевагу порівняно $з$ тими, які їм не відповідають. Іншим ключовим компонентом $\epsilon$ система відстеження того, хто відвідує захід, та інформування учасників у випадку спалаху захворювання під час заходу.

3. Окупність подій при проведенні їх онлайн. Якщо організатори подій проводять безпечну версію свого заходу, не розглядаючи при цьому питання соціального дистанціювання, тестування, відстеження, дезінфекції, подорожей та можливості нести правову відповідальність, єдиним варіантом є віртуальні події. Але, справа в тому, що достатньо складно створити дохід на віртуальних подіях [10].

Ось деякі ключові міркування щодо створення майбутнього доходу:

1. Застосування абонентної моделі для заходів з квитками. Продаж абонементу створює більшу цінність, ніж продаж квитків на окремі події.

2. Створення спільноти. Особливі події мають можливість створити спільноту для того, щоб учасники постійно спілкувались. Немає сенсу кожного разу реєструвати учасників.

3. Пропозиція кращого змісту. Зміст повинен бути організований кращим способом. Це не може бути чотиригодинне відео для перегляду без реплік. Відео слід розбити на сесії, додавати нотатки, пропонувати різні формати мультимедіа та включати доступ лише для аудіо.

4. Пропозиція зустрічей один на один та взаємодія (нетворкінг). Нетворкінг - це триваюча боротьба за віртуальність, яка не забезпечує досягнення бізнес-цілей. Для виставок слід наголосити на тому, щоб забезпечити кращі можливості для створення потенційних клієнтів.

4. Гібридні івенти - це майбутнс івент-індустрії. Учасники івентів ще довго будуть боятися відвідувати «живі» події. А нестабільна статистика захворюваності ще не раз призведе до повторної вимушеної ізоляції.

Не буде івентів заради івентів! Попрацювавши i поспілкувавшись онлайн протягом декількох місяців, люди зрозуміли: іноді немає сенсу долати тисячі кілометрів, щоб зустрітися на кілька годин. Прийдешня фінансова криза змусить компанії значно скоротити бюджети на корпоративні поїздки. Віртуальні контакти стануть нормою.

Першими до життя повернуться музичні фестивалі та особисті (сімейні) свята. Але корпоративні заходи, а це один із стовпів івент-індустрії відновляться останніми. Так, в Microsoft вже заявили про заборону корпоративних поїздок на події за участю понад 50 осіб: як мінімум, до 3-го кварталу 2021 року [11].

Офлайн івенти не зможуть збирати всіх зацікавлених відвідувачів. Ймовірно, що учасники, які входять до «групи ризику», дадуть перевагу підключитися до заходу онлайн.

До пандемії деякі організатори організовували гібридні заходи. Онлайн-компонент був трудомістким, таким що віднімав час. Мало хто розумів, наскільки це необхідно, i який дає ефект.

Зараз все змінилося. Онлайнмовлення стало пріоритетним. Але у багатьох організаторів виникає маса питань щодо підготовки повно цін- 
ного комбінованого івенту. Як підготувати все так, щоб івент дійсно залучав аудиторію, а не перетворився на нудну трансляцію по веб-камері? Ось кілька ідей та варіантів форматів:

1. Менше конференцій, більше телешоу. Експерти очікують, що події в онлайні змінять формат: 3 живими спікерами, обмеженою аудиторією, професійним ведучим i потужною технічною інфраструктурою.

2. Якісні канали для мовлення i швидкісний інтернет. Мовлення має бути стабільним і надійним. Доведеться знаходити провайдерів для онлайн-трансляції і працювати через ï ресурси та інструменти. Послуга високошвидкісного Інтернету на локації стане нормою.

3. Повноцінні інструменти для інтерактивної взаємодії. Можливості для коментарів, спілкування і оцінки спікерів стануть нормою для гібридних подій.

4. Адаптація платформ під гібридні заходи. Наприклад, можливість підключення до онлайн-мовлення через мобільний додаток. Організаторам будуть цікаві інструменти для монетизації мовлення.

5. Збереження ключової функції модератора. Особливо, якщо він вміє працювати 3 живою і онлайнаудиторією, розуміє іiї потреби та очікування.

5. Нові пріоритети в проведені івент-заходів. Синдром Втрачених Можливостей (СВM) або FOMO (від англ. «Fear of missing out») - нав'язлива боязнь пропустити цікаву подію або гарну можливість, що провокується, в тому числі, переглядом соціальних мереж. Чотири людини $з$ десяти відчували СВМ хоча 6 іноді, причому чоловіки частіше, ніж жінки. За іншими даними, страх пропустити щось важливе відчувають взагалі 56 \% людей. Це явище характеризується непереборним бажанням постійно залишатися в курсі справ друзів і знайомих. СВМ також часто називають почуттям жалю, яке може призвести до страху пропустити цікаву подію, можливість поспілкуватися 3 друзями або знайомими, отримати новий досвід або матеріальну вигоду [12].

Віртуальні події повільно вбивають найбільшу тактику маркетингу подій за останні кілька років - FОМО або CВM. FOMO була однією $з$ найефективніших технологій продажу квитків i збудження інтересу до подій. Але пандемія, яка швидко зупинила івенти по всьому світу, змусила мільярди людей сидіти вдома. Ніхто цього не очікував, що призвело до зростання кількості віртуальних подій. Несподівано виявилося, що можна відвідати десятки заходів, не виходячи $з$ дому. Отже, ці події, в більшості випадків, були безкоштовними. Івенти 3 високими цінами на квитки стали несподівано доступними. Більше не потрібно подорожувати на інший кінець світу. $\mathrm{Bce}$, що необхідно, доступно онлайн. Це стало одкровенням для аудиторії та безвихідною ситуацією для представників івент-індустрії.

Багато івентів існували тільки завдяки продажу квитків і спонсорству. Виправдати високу ціну квитків за онлайн-доступ до трансляції нелегко. Спонсори в змозі самостійно зареєструвати облікові записи в сервісах для прямих трансляцій і проводити івенти 3 рекордними кількостями переглядів.

Цей масштабний вимушений експеримент з віртуальними подіями дає івент-індустрії безпрецедентну можливість продемонструвати себе. Якщо раніше подія збирала на локації 1000 відвідувачів, то перехід до онлайн формату дозволяє залучити 10000 учасників та більше. Це дає неймовірні можливості для бізнесу.

Якщо раніше обмежений бюджет івенту змушував відмовлятися від креативних ідей, то зараз організатори зможуть створити подію, не обмежуючи себе. Адже єдина посправжньому велика стаття бюд- 
жету - це оплата послуг платформи для трансляції. У організаторів більше немає бар'єрів. По-справжньому, гнучкі професіонали вже перебудувалися i працюють в нових умовах. Вони займаються звичною роботою $\mathrm{i}$ це вражає.

Індустрія офлайн подій буде відновлюватися, а з нею повернеться і синдром втраченої вигоди. I з часом на ринку встановиться баланс: ті, хто цінували офлайн івенти і нудьгували за ними - повернуться до звичного формату. Решта проводитимуть гібридні івенти або організовуватимуть тільки онлайн-заходи [11].

Правда полягає в тому, що мільярди людей, які пережили карантин вдома, оцінили якість хороших віртуальних івентів. I якщо раніше ці заходи займали незначну нішу, то зараз це змінилося. У сучасному світі вони можуть стати панацеєю для населення, схильного до вірусних атак. Вони можуть врятувати планету, яка страждає від величезної кількості авіаперельотів.

Потрібно повернути FOMO до віртуальних подій. При плануванні будь-якого заходу є бюджет і мета проєкту. Інвестування в створення віртуальних подій має потребу в установці бар'єрів для входу. Деталізуємо це для випадку проведення науково-практичної конференції в форматі онлайн.

Мотивацію та переваги участі у науково-практичних конференціях було описано у [13-15]. Визначимо цінності для організатора конференції, а саме - Одеського національного морського університету (ОНМУ). Оскільки ВНЗ України є неприбутковою організацією, то при проведенні такого івенту університет отримує таку нову цінність, як підвищення статусу ВНЗ в освітньому просторі, укріплення рейтингу ОНМУ серед українських та закордонних ВН3, просування іміджу ОНМУ і підвищення інтересу до його бренду - це «Водный». По-друге, формування інтересу до певних напрямків знань або освітніх програм та приплив абітурієнтів. По-трете, будь-який івент-захід є індикатором, що проявляє позитивне ставлення до університету в цілому та його випускових кафедр.

Організаторам необхідно ставити високі цілі, щоб їх віртуальні івенти викликали жвавий інтерес i бажання заплатити за участь у них. Віртуальні події вимагають інновацій, творчості та руйнування старих підходів. Краще бути готовими до радикальної зміни очікувань. Якщо раніше для відвідувачів івентів першочерговий інтерес представляли:

1. Контент (насиченість інформації, отриманої на конференції);

2. Взаємодія між учасниками події (нетворкінг);

3. Розваги (кава-брейки, майстер-класи за різною тематикою, сувенірна продукція 3 логотипом івенту), то в умовах пандемії та 3 розвитком онлайн івентів шкала потреб змінилася на:

1. Значимість комунікацій (нетворкінг, який перетвориться на довгострокові відносини між учасниками івент-заходу);

2. Розваги (кава-брейки, майстер-класи за різною тематикою, сувенірна продукція 3 логотипом івенту);

3. Контент (насиченість інформації, отриманої на конференціï).

Організатори, які врахують нові потреби аудиторії, досягнуть високої ефективності.

6. Аудіо-формат - як альтернатива платформи ZOOM. Втома від платформи ZOOM стимулює новий спосіб проведення заходів: лише аудіо. Це може здатися суперечливим через ризик падіння залученості відвідувачів, але суть у тому, щоб запропонувати варіанти, які більш орієнтовані на потреби відвідувачів. Зручність - головне для успіху формату. 


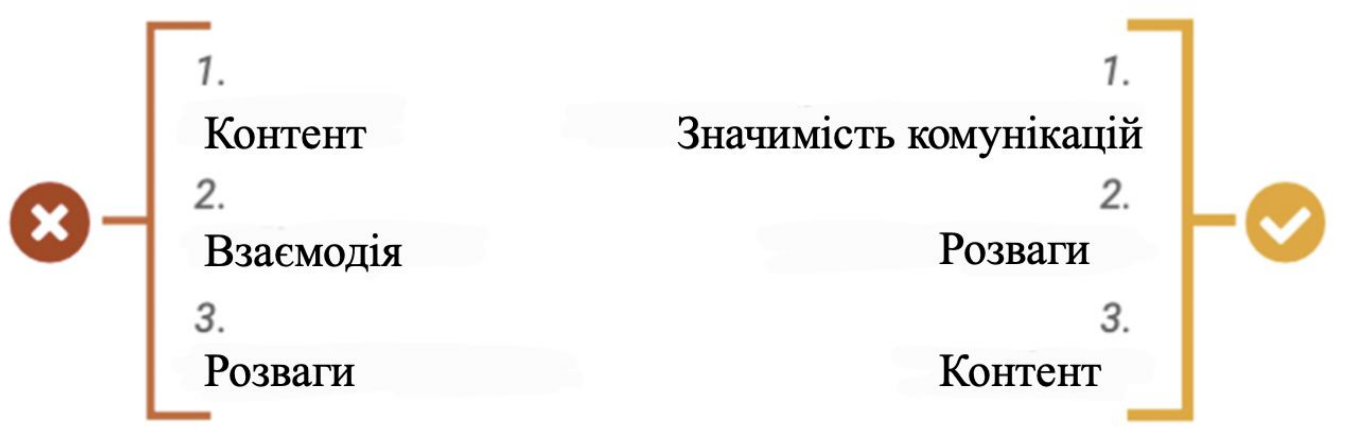

Рисунок. Потреби відвідувачів івент-заходів

Джерело: перекладено авторами на основі [9]

Наприклад, абсолютно усі учасники можуть брати участь у заході через телефонний зв'язок. При цьому ключова перевага - в мобільності та портативності формату. Пропонування аудіовідвідувань може допомогти створити додаткові нові можливості - брати участь у платних віртуальних подіях у якості слухача, а також надати більш зручні можливості відвідування тим, хто відчуває себе пригніченим зустрічами ZOOM.

Більше того, слухання, на відміну від перегляду, стимулює частину мозку, що змушує нас візуалізувати інформацію. Для того, щоб впровадити аудіо-формат у подію треба спланувати зміст виступу так, щоб не було посилань на візуальні ресурси. До того ж можна застосувати подкаст для події, який слід оптимізувати для основних мобільних платформ.

7. Переосмислення емоційної залученості відвідувачів. Перехід до онлайну був очевидним рішенням для більшості івентів. У той же час утримання учасників - найбільша проблема, з якою стикаються організатори заходів при їх проведенні у віртуальному просторі.

Один із способів - це розглядати онлайн як окремий формат, який не має нічого спільного 3 традиційним заходом. Віртуальні події, на відміну від класичних, не можуть задіяти всі почуття аудиторії, отже для залучення учасників більше уваги слід приділяти емоційній складовій. Потрібно створювати контент, здатний знаходити живий відгук у аудиторії. Це означає, що необхідно торкатися актуальних проблем і заохочувати людей демонструвати емоції.

У віртуальних подій $є$ недолік: вони не можуть забезпечити повне занурення учасників. Тому доводиться зосередити зусилля на візуальній та аудіо складових, щоб передати всі необхідні емоції. Сучасні технології дозволяють зробити багато. Використовуючи можливості віртуальної реальності, можна створити відчуття присутності й подарувати абсолютно новий користувальницький досвід. Недоліком таких рішень $\epsilon$ дороговизна і тривалість, але для великих івентів - це виправдані інвестиції.

Висновки. Досліджені тренди івент-заходів на 2021 рік та особливості організації івент-проєкту науково-практичної конференції у ВНЗ України, що дозволило виявити наступні цінності для організатора та учасника конференції (таблиця). 
Цінності для учасників при проведенні ділового заходу - конферениії у ВНЗ Украйни

\begin{tabular}{|c|c|}
\hline Для організатора & Для учасника \\
\hline $\begin{array}{l}\text { Підвищення статусу ВНЗ в освітньому } \\
\text { просторі, укріплення рейтингу ВНЗ } \\
\text { серед українських та закордонних вузів, } \\
\text { просування іміджу ВНЗ і підвищення } \\
\text { інтересу до иого бренду }\end{array}$ & $\begin{array}{l}\text { Прагнення до пізнання і сприйняття } \\
\text { нового, невідомого (пізнавальні та } \\
\text { творчі потреби) або потреба в творчій } \\
\text { діяльності }\end{array}$ \\
\hline $\begin{array}{l}\text { Просування освітніх продуктів на ринку } \\
\text { праці та в соціальних мережах }\end{array}$ & $\begin{array}{l}\text { Підвищення якості підготовки учас- } \\
\text { ника як фахівця й готовність до підго- } \\
\text { товки самостійного дослідження }\end{array}$ \\
\hline $\begin{array}{l}\text { Формування інтересу до певних } \\
\text { напрямків знань або освітніх програм }\end{array}$ & $\begin{array}{l}\text { Збір інформації, вивчення } \\
\text { літературних джерел }\end{array}$ \\
\hline Приплив абітурієнтів до ВНЗ & $\begin{array}{l}\text { Розвиває лідерські якості, вміння } \\
\text { спільного вирішення задач, розвиток } \\
\text { аналітичних здібностей тощо }\end{array}$ \\
\hline $\begin{array}{l}\text { Взаємозв'язок між викладачем та сту- } \\
\text { дентом, розкриття творчого потенціалу } \\
\text { та наукового пошуку студентів при } \\
\text { підготовці тез конференції та доповідей }\end{array}$ & $\begin{array}{l}\text { Вміння викладати результати дослід- } \\
\text { ження в тезисній формі, публікація } \\
\text { дослідження }\end{array}$ \\
\hline $\begin{array}{l}\text { Будь-який івент-захід є індикатором, що } \\
\text { проявляє позитивне ставлення до ВНЗ та } \\
\text { випускових кафедр та підвищення } \\
\text { конкурентоспроможності ВНЗ в } \\
\text { освітньому середовищі }\end{array}$ & Практика ведення дискусій \\
\hline $\begin{array}{l}\text { Після проведення заходу залишається } \\
\text { база даних учасників та їх контакти, } \\
\text { розміщення інформації про проведений } \\
\text { науковий захід на порталі ВНЗ, розсилка } \\
\text { друкованих збірників учасникам та } \\
\text { передача їх до Наукової бібліотеки ВНЗ }\end{array}$ & $\begin{array}{l}\text { Можливість поспілкуватися з експер- } \\
\text { тами, лідерами та професіоналами у } \\
\text { даній галузі, у тому числі в міжнарод- } \\
\text { ному форматі }\end{array}$ \\
\hline
\end{tabular}

\section{Джерело: створено авторами}

Результати викладеного дослідження прийняті для використання у проведенні міжнародної науковопрактичної конференції «Проєктний та логістичний менеджмент: нові знання на базі двох методологій» (лист Інституту модернізації змісту освіти № 221/10-37 від 13.01.2021 щодо Переліку наукових конференцій 3 проблем вищої освіти і науки у 2021 році) на базі випускової кафедри «Управління логістичними системами і проєктами» ОНМУ. Також результати роботи використані в освітньому процесі при проведенні практичних занять 3 дисципліни «Event-management» для студентів другого курсу спеціальності 073 «Менеджмент» освітньо-професійної програми «Управління проєктами» Навчально-наукового інституту морського бізнесу ОНМУ, що підтверджує акт впровадження. 


\section{СПИСОК ЛІТЕРАТУРИ}

1. Хальибаур У., Йеттингер Э., Кнаусе Б., Мозер Р., Целлер М. Eventменеджмент / пер. с нем. Фоминой, 2007. М.: Эксмо. 384 с.

2. Шумович А.В. Великолепные мероприятия. Технологии и практика eventmanagement. Изд-во: Манн, Иванов и Фербер, 2009. 336 с.

3. Shone A., Parry B. Successful event management: a practical handbook. Cengage Learning EMEA, 2004. P. 13.

4. Management of Event Operations / J. Tum, P. Norton, J. Nevan Wright. Elsevier Butterworth-Heinemann, 2006. 279 p.

5. Онлайн-револючия: что ждет рынок мероприятий. 05.06.2020.URL: https://proman.com.ua/35876-onlajn-revolyutsiya-chto-zhdet-rynokmeropriyatij-alena-zhupikova

6. Do Virtual and In-Person Attendees at Hybrid Events Actually Want an Integrated Experience? 15.01.2021. URL: https://www. eventmanagerblog.com/hybrid-event-audience-interaction

7. Event Trends That Will Shake Up Meetings \& Group Business in 2021. URL: https://www.socialtables.com/blog/event-planning/event-trends

8. Emerging Event Trends That Will Shape In Industry in 2021. URL: https://blog.bizzabo.com/event-trends

9. Event Manager Blog Event Trends for 2021 / Event Manager Blog. 2020. URL: https://www.eventmanagerblog.com

10. Сайт з івент-маркетингу: теорія і практика. 2020. URL: https://www. eventmarket.ru.

11. Матвійчук Т. Гібридні івенти - наме очевидне майбутнє. 16.07.2020. URL: https://arenacs.ua/ua/base/gibridnye_iventy_nashe_budushhee

12. FОМО, або страх щось пропустити: як розпізнати $\bar{i}$ боротися з ним. 14.11.2019. URL: https://novarobota.ua/ua/articles-jobseeker/fomo-ilistrakh-upustit-chto-to-kak-raspoznat-i-borotsya-s-nim-265

13. Жученя К. Чому я беру участь у студентських конферениіях $i$ де їх шукаю? 19.02.2020. URL: https://happymonday.ua/studentski-konferentsiyii-de-yih-shukaty

14. Леушканова С.В. Особенности мотивации научной деятельности преподавателей вуза // Наука, образование, общество. URL: http: // journal.sakhgu.ru/ archive/2004-03-1.doc.

15. Кущенкко І.Ю. Мотивачія науково-досліднищької діяльності учнів запорука успішності в навчальній та позанавчальній роботі // Теорія та методика управління освітою. URL: http://tme.umo.edu.ua/ docs/1/ 08 kiunpr.pdf

\section{REFERENCES}

1. Khaljcbau,r U., J'ettyngher, E., Knause, B., Mozer, R. \& Celler, M. (2007). Event-menedzhment [Event-management]. Per. s nem. Fomynoj. M: Эksmo. 384 p. [in Russian].

2. Shumovych, A.V. (2009). Velykolepnble meropryjatyja. Tekhnologhyy y praktyka even-management [Great events. Event-manage-ment technologies and practice.]. Mann, Yvanov y Ferber. 336 p. [in Russian].

3. Shone, A. \& Parry, B. (2004). Successful event management: a practical handbook. Cengage Learning EMEA. pp. 13. [in English].

4. Tum, J., Norton, P. \& Nevan Wright, J. (2006). Management of Event Operations / Elsevier Butterworth-Heinemann, 279. [in English]. 
5. Onlajn-revoljucyja: chto zhdet rynok meropryjatyj [Online revolution: what awaits the event market]. 05.06.2020. Retrieved from: https://proman. com.ua/35876-onlajn-revolyutsiya-chto-zhdet-rynok-meropriyatij-alenazhupikoval

6. Do Virtual and In-Person Attendees at Hybrid Events Actually Want an Integrated Experience? Retrieved from: https://www.eventmanagerblog. com/ hybrid-event-audience-interaction (accessed 15 January 2021).

7. Event Trends That Will Shake Up Meetings \& Group Business in 2021. Retrieved from: https://www.socialtables.com/blog/event-planning/eventtrends/ (accessed 3 January 2021).

8. Emerging Event Trends That Will Shape In Industry in 2021. Retrieved from: https://blog.bizzabo.com/event-trends (accessed 10 January 2021).

9. Event Manager Blog Event Trends for 2021 (2020) Event Manager Blog. Retrieved from: https://www.eventmanagerblog.com (accessed 15 January 2021).

10. Sajt $z$ ivent-marketynghu: teorija $i$ praktyka (2020) Retrieved from: https://www.eventmarket.ru. (accessed 15 January 2021).

11. Matvijchuk, T. (2020). Ghibrydni iventy-nashe ochevydne majbutnje [Hybrid events - our obvious maybut]. Retrieved from: https:// arenacs. ual ual base/gibridnye iventy nashe_budushhee/ (accessed 10 March 2021).

12. FOMO, abo strakh shhosj propustyty: jak rozpiznaty $i$ borotysja z nym [FOMO, for fear of missing: how to recognize and fight with him] (2019). Retrieved from:https://novarobota.ua/ua/articles-jobseeker/fomo-ili-strakhupustit-chto-to-kak-raspoznat-i-borotsya-s-nim-265 (accessed 15 January 2021).

13. Zhuchenja, K. (2020). Chomu ja beru uchastj u studentsjkykh konferencijakh $i$ de jikh shukaju? [Why I participate in student conferences and where I look for them]. Retrieved from: https://happymonday.ua/studentski-konferentsiyi-ide-yih-shukaty(accessed 10 March 2021).

14. Leushkanova, S.V. (2004). Osobennosty motyvacyy nauchnoj dejateljnosty prepodavatelej vuza [Features of motivation of scientific activity of university teachers]. Nauka, obrazovanye, obshhestvo - Science, education, society. Retrieved from: http: // journal.sakhgu.ru/ archive/2004-03-1.doc. (accessed 20 March 2021).

15. Kushhenko, I.Ju. (2010). Motyvacija naukovo-doslidnycjkoji dijaljnosti uchniv - zaporuka uspishnosti v navchaljnij ta pozanavchaljnij roboti. Teorija ta metodyka upravlinnja osvitoju. Retrieved from: http://tme.umo. edu. ua/ docs/1/08kiunpr.pdf (accessed 20 March 2021).

Стаття надійшла до редакиії 19.02.2021

Посилання на статтю: Семенчук К.Л., Нечит Д.Д. Управління просктами згідно 3 трендами event-галузі // Розвиток методів управління та господарювання на транспорті: Зб. наук. праць, 2021. № 1 (74). С. 76-86. DOI 10.31375/2226-1915-2021-1-76-86.

Article received 26.02.2021

Reference a JournalArtic: Semenchuk Kateryna \& Nechyt Daria (2021). Project management according to event industry trends. Development of management and entrepreneurship methods on transport. 1 (74), 76-86. DOI 10.31375/2226-1915-2021-1-76-86. 